\title{
Phytochemistry, Antioxidant Activity and Cytotoxicity Evaluation of Black-White Fungus Auricularia sp. against Breast MCF-7 Cancer Cells
}

\author{
Ade Arsianti ${ }^{1,2, *}$, Arfi Rabbani ${ }^{3}$, Anton Bahtiar ${ }^{4}$, Norma Nur Azizah², Lince Dameria Nadapdap ${ }^{2}$, Ajeng \\ Megawati Fajrin ${ }^{1}$
}

Ade Arsianti ${ }^{1,2, *}$, Arfi Rabbani ${ }^{3}$,

Anton Bahtiar', Norma Nur Azizah², Lince Dameria Nadapdap², Ajeng Megawati Fajrin ${ }^{1}$

'Department of Medical Chemistry, Faculty of Medicine, University of Indonesia, Jakarta, INDONESIA.

${ }^{2}$ Drug Development Research Cluster, Indonesia Medical Education and Research Institute (IMERI), Faculty of Medicine, University of Indonesia, Jalan Salemba Raya 6 Jakarta 10430, INDONESIA.

${ }^{3}$ Medical Student, Faculty of Medicine University of Indonesia, Jakarta, INDONESIA ${ }^{4}$ Department of Pharmacology, Faculty of Pharmacy, University of Indonesia, Depok INDONESIA.

\section{Correspondence}

\section{Ade Arsianti}

Department of Medical Chemistry, Faculty of Medicine University of Indonesia, Depok, INDONESIA.

Phone no: +6281312581253

E-mail: arsi_ade2002@yahoo.com

History

- Submission Date: 25-09-2021;

- Review completed: 13-10-2021;

- Accepted Date: 21-10-2021.

DOI : 10.5530/pj.2022.14.1

Article Available online

http://www.phcogj.com/v14/i1

Copyright

(C) 2022 Phcogj.Com. This is an openaccess article distributed under the terms of the Creative Commons Attribution 4.0 International license.

ABSTRACT

Introduction: Cancer is a non-communicable disease with over 18.1 million new cases and 9.6 million deaths annually according to WHO. Breast cancer is the number two highest count type of cancer trailing behind lung cancer. Treating cancer is expensive and have various side effects. Active components found in plants or fungi that have antioxidant and cytotoxic activity towards cancer cells, could be an alternative for anticancer. One of the fungi that is potentially developed as an anticancer, are the genus of Auricularia sp. also known as black-white fungus. This study aims to determine the phytochemicals components, antioxidant activity and cytotoxic effect of the Auricularia sp. towards MCF-7 breast cancer cells. Methods: Dried black-white fungus of Auricularia sp. grinded into a fine powder. Then, multilevel maceration is done with the n-hexane, ethyl acetate, ethanol as solvents. The extracts of black-white fungus undergo phytochemical screening and thin layer chromatography (TLC), followed by measuring antioxidant and evaluating the cytotoxic activity towards MCF-7 breast cancer cells. Results: black-white fungus of Auricularia sp. contained secondary metabolites of flavonoids, alkaloids, and triterpenoids and a total of 17 other phytochemical components. Ethyl acetate extract of black-white fungus showed a weak antioxidant activity towards DPPH free radical with $I C_{50}$ of $215.51 \mu \mathrm{g} / \mathrm{mL}$ and a very active cytotoxic activity on MCF-7 cells with $\mathrm{IC}_{50}$ of $0.21 \mu \mathrm{g} / \mathrm{mL}$. On the other hand, ethanol and n-hexane extracts of black-white fungus are categorized with an active cytotoxic activity on MCF-7 cells with $I C_{50}$ of $29.28 \mu \mathrm{g} / \mathrm{mL}$ and 50.39 $\mu \mathrm{g} / \mathrm{mL}$, respectively. Conclusion: Black-white fungus Auricularia sp. that had anticancer activity towards breast MCF-7 cells should be considered as an alternative treatment for breast cancer therapy.

Key words: Phytochemistry, Antioxidant, Cytotoxicity, Black-white fungus Auricularia sp., MCF-7 cells.

\section{INTRODUCTION}

Cancer is one of the examples of non-communicable disease and it is a very concerning disease in the world. The definition of cancer is when malignant forms of abnormal cell growth that develops in one of the organs in the body. It arises from genetic mutation, which remove the normal checkpoints on cell growth. These abnormal cells continue to grow and divide to produce tumors. Cancer cells could spread to adjacent structures and infect through lymph or blood circulation. ${ }^{1}$ In 2018 , there are 18.1 million new cases and 9.6 million deaths according to WHO (World Health Organization). One in five men will develop cancer, while one in six women will develop cancer. Breast cancer has the second highest number, behind lung cancer. ${ }^{2}$ The general treatment for breast cancer differs according to the stages. ${ }^{3}$ There are four stages in cancer, stage I means that the cancer is small and it is located only in a small area, stage II and III could be define as large cancer that has grown into lymph nodes or nearby tissue, while stage IV means that the cancer has spread to other organs. ${ }^{4}$

Nowadays there are various treatments that could be done to upper hand cancer. Ranging from surgery to therapy such as chemotherapy and hormone therapy. But these treatments are not cheap and have a various side effect such as, headache, fatigue, weakness, hair loss, nausea, vomiting, diarrhea, abdominal cramps, mouth sores, dry mouth, memory impairment, and numbness. ${ }^{5}$ Therefore, we need to find other cheaper alternatives that could be used for treating cancer.

Lovit CJ, et al. stated that doxorubicin, one of the chemotherapy agent for MCF-7 breast cancer cells, could develop resistance towards breast cancer cells through extra cellular matrix protein. ${ }^{6}$ Other prospecting natural resource for treating cancer is the edible fungus, which is currently use for the anticancer that is containing bioactive compounds. This edible fungus shows significant anti-aromatase effect that is crucial for treating breast cancer. According to Petrova et al., one of the most potent fungus that showed great result was the Agaricus bisporus, Pleurotus ostreatus, and Auricularia sp., with an increase in its extract concentration, there was a decrease in the testosterone-dependent aromatase activity. This results suggest that testosterone may have compete with some components from the fungus extracts, which produce a protective effect towards the patient. ${ }^{7}$ Even though there are thoroughly research about some fungus about their potential anticancer substance, there are only few reports of research about black-white fungus with the latin name of Auricularia cornea, which has the same genus with one of the most potent fungus for anticancer activity, Auricularia sp. ${ }^{8}$ This fact prompted us to explore more about blackwhite fungus Auricularia sp. for its antioxidant and cytotoxicity towards breast MCF-7 cancer cell line. 


\section{MATERIAL}

\section{Black-white fungus Auricularia sp.}

Dried black-white fungus Auricularia sp. (Figure 1), was purchased from AEON supermarket, Tangerang, Banten, Indonesia. This flora is belonged in the fungi kingdom, Basidiomycota phylum, agaricomycetes class, auriculariales order, auriculariaceae family, auricularia genus and cornea species. ${ }^{8}$ This fungus is normally found on dead wood or even on dead parts of living trees and has been an edible food from late 18th century in Chinese dishes. The fruiting bodies contains variety of nutrients including protein, carbohydrates, amino acids, crude fibers, and some microelements. While the polysaccharides have been shown to reduce blood fat and have antioxidant properties, cancer reducing activities, and immune enhancing. ${ }^{8}$

\section{Breast MCF-7 cancer cell lines}

MCF-7 breast cancer cell is the cell culture collection of the Medical Chemistry Department, Faculty of Medicine, University of Indonesia.

\section{METHODS}

\section{Research Design}

This research is an experimental study, which is divided into two processes, analyzing the phytochemicals content of Black-White fungus Auricularia sp., evaluating the antioxidant activity with DPPH assay and cytotoxic activity with MTT assay.

\section{Population and Sample}

The research started from preparing the sample and extracting it with three different solvents of $\mathrm{n}$-hexane, ethyl acetate and ethanol. These extracted samples will be analyzed its phytochemical contents, antioxidant and anticancer activity. The sample will be grinded into a fine powder. Three organic solvents that are used to extract the fungus are non-polar solvent of n-hexane, semi-polar solvent of ethyl acetate and polar solvent of ethanol. Extracts of Black-White fungus Auricularia sp. are going to be used for phytochemical screening, measuring its antioxidant activity by DPPH method, and evaluating its cytotoxic activity on breast MCF-7 cells by MTT assay.

\section{Data Collection Method}

\section{Maceration}

Dried Black-White fungus Auricularia sp. will be soften by mixergrinder until it becomes a fine powder. Subsequently, the powder is macerated and extracted consecutively with three different solvent that are n-hexane (non-polar solvent), ethyl acetate (semi-polar solvent), and ethanol (polar solvent). Maceration by each solvent will be done two times at room temperature. After maceration process, the

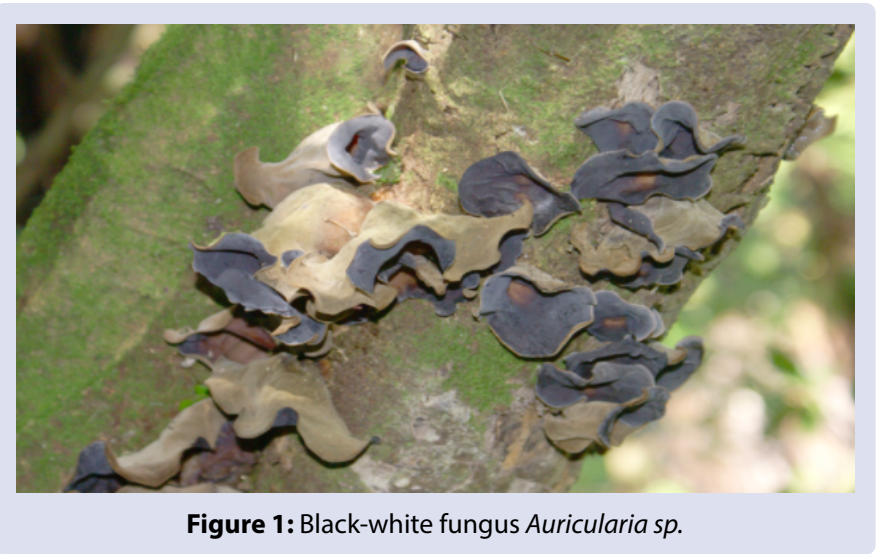

mixture will be filtered, resulting into liquid and solid form. The liquid (filtrated part) of n-hexane (non-polar), ethyl acetate (semi-polar), and ethanol (polar) will be collected, then will be solidified by vacuum-dry technique resulting in three extracts, $n$-hexane extract, ethyl acetate extract and ethanol extract of Black-White fungus Auricularia sp. respectively. These three extracts will be the main component for TLC, phytochemical screening, DPPH assay, and MTT assay.

\section{Thin Layer Chromatography}

Thin layer chromatography (TLC) is a technique that could be used for various purposes, such as determine the number of components in a mixture, verify the purity and identity of a compound, monitor the progression of a reaction, determining the solvent composition, and analyzing the fractions that are obtained from the column chromatography. There are two phases in this method, the stationary, which could be made by plastic, glass or metal that is layered by alumina or silica, and mobile phase, which is the liquid form that ascend to the thin layer of the stationary phase. ${ }^{9}$

TLC plates will be cut out with the length of $5 \mathrm{~cm}$ and there will be a straight line in $0,5 \mathrm{~cm}$ in each end. Three dots representing three extracted solvents are drawn in the straight line. After placing the extracted samples into the dots, the TLC will be place inside the chamber that contains the mobile phase, which is a $10 \mathrm{ml}$ mixture of hexane and ethyl acetate with a ratio of 4:1. The mobile phase will ascend towards the top until it reaches the opposite straight line. The TLC will be dried out and observed under an ultraviolet lamp with the wavelength of $254 \mathrm{~nm}$ and $366 \mathrm{~nm}$. Rf will be measured by the distance travelled by the samples divided by the distance travelled by the mobile phase (Figure 2). ${ }^{9}$

\section{Qualitative Phytochemical Screening ${ }^{10,11}$}

\section{Alkaloids Screening}

Prepare the solution by adding $2 \mathrm{~mL}$ of sample extract with $5 \mathrm{~mL}$ of $\mathrm{CHCl}_{3}$ and 2 drops of $\mathrm{NH}_{4} \mathrm{OH}$. The mixed solution will be filtered and heated. Add $5 \mathrm{~mL}$ of $\mathrm{HCl} 2 \mathrm{~N}$ and divide it into three different reaction tubes. First tube is blank, second tube added by 3 drops of Dragendroff reagent, third tube added by 3 drops of Meyer reagent. Alkaloids is positive if the second and third tube changes into yellowish color.

\section{Flavonoids Screening}

$1 \mathrm{ml}$ sample extract combined with a $0.5 \mathrm{~mL}$ of $\mathrm{HCl}$ and $4 \mathrm{~cm}$ of $\mathrm{mg}$ strip. Appearance of yellow, red, or green color the presence of flavonoids.

\section{Saponins Screening}

$1 \mathrm{mg}$ of extract is diluted up to $10 \mathrm{~mL}$ with distilled water. For 10 seconds, the suspension is mixed. Formation of two-cm layer of foam that is table for 10 minutes detects that there is saponins. This could further be confirmed by adding one drop of $\mathrm{HCl} 2 \mathrm{~N}$.

\section{Tannin Screening}

$1 \mathrm{~mL}$ of $10 \% \mathrm{FeCl}_{3}$ is mixed with $1 \mathrm{ml}$ of the extract. Formation of greenish-black or dark blue color indicates that there is a presence of tannis.

\section{Glycosides Screening}

$0.1 \mathrm{~mL}$ extract is evaporated above a boiling water. Add $1 \mathrm{~mL}$ of sodium acetate hydrate and $2 \mathrm{~mL}$ of $\mathrm{H}_{2} \mathrm{SO}_{4}$. Changing to blue or green color results in a positive result.

\section{Triterpenoid and Steroid Screening}

$2 \mathrm{~mL}$ of sample extract will be evaporated in a porcelain bottle. The evaporation will be dissolved with chloroform and acetic anhydrate 


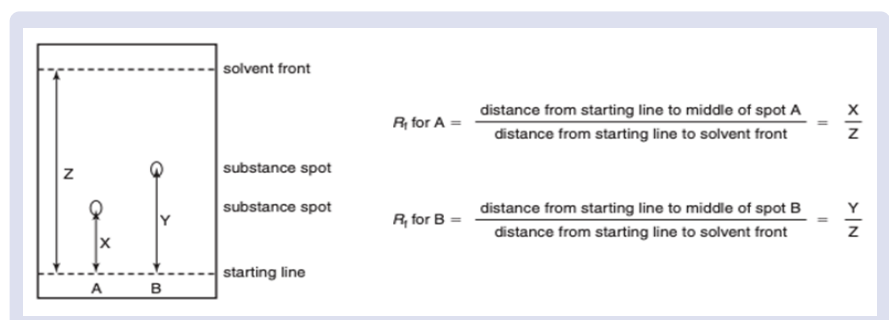

Figure 2: Calculation of RF Value. A and B different extract. (X distance from starting line to middle of spot $A, Y$ distance from starting line to middle of spot B, Z distance from starting line to solvent front).

with $0.5 \mathrm{~mL}$ each. After that, $2 \mathrm{~mL}$ of sulfuric acid will be inserted through the wall of the bottle. The result is positive for triterpenoid if there is a ring formation with brown or violet color. While as, bluegreenish ring formation is positive for steroid.

\section{DPPH Assay}

DPPH Assay is a method to evaluate the antioxidant activity from the sample's extract. Firstly, Methanol will be diluting the DPPH within several test tube that contains different concentration of the extract ranging from $50-250 \mu \mathrm{g} / \mathrm{mL}$ and one control sample without the extract. Subsequently, the test tubes will be shacked and incubated for 30 minutes at temperature of $37^{\circ} \mathrm{C}$. The incubated samples will be moved into microplate and measured through spectrophotometer at wavelength of $517 \mathrm{~nm}$. Determining the antioxidant activity is done by the absorbance results. The higher the antioxidant activity results in lower absorbance. The radical scavenging activity is calculated through the following equation. ${ }^{12}$

Inhibition $(\%)=\frac{\text { Abs Control }- \text { Abs Sample }}{\text { Abs Control }} \times 100$

IC50 defined as the amount of concentration of the sample that is needed to inhibit $50 \%$ of the absorbance. The lower the amount of extract that could reach IC50 results in a higher scavenging activity. ${ }^{12}$

\section{MTT Assay}

MTT is dissolve by PBS (Phosphate Buffer Saline) with pH of 7.4 until the concentration reaches $5 \mathrm{mg} / \mathrm{mL}$. The MTT mixture will be filtered by $0.2 \mu \mathrm{M}$ filter and moved into a sterile and light-protected container. The solution will be kept in light-protected storage and in a temperature of $4^{\circ} \mathrm{C}$. The cultured cells are transferred and inoculated for 24 hours into the 96-well plate. Each well is added with different concentration of the extract and incubated for 48 hours. ${ }^{13}$

To perform this method, the wells that consist of the cell lines and 10mg of extract, which has been incubated for 48 hours, is mixed with $25 \mu \mathrm{L}$ of MTT solution and incubated for 4 hours at $37^{\circ} \mathrm{C}$. Then, solubilized the solution with $100 \mu \mathrm{L}$ of DMSO. Lastly, read the absorbance with a spectrophotometry at wavelength of $570 \mathrm{~nm}$. The IC50 is calculated from the following equation. ${ }^{13}$

Cell cytotoxicity $(\%)=100-\left(\frac{\text { Abs Control }- \text { Abs Sample }}{\text { Abs Control }} \times 100\right)$

\section{Data Analysis}

Data analysis will be done through Microsoft Excels and 20th version of SPSS. The data will comprise of evaluation of Black-White fungus Auricularia sp.'s phytochemical components, scavenging activity, and cytotoxic activity. Phytochemical components will be presented as positive or negative values. Microsoft Excels will be used to calculate the linear regression and R-squared of the scavenging activity and cytotoxic activity, in theory if the scavenging activity increases, so does the cytotoxic activity. Normality and Kruskal-Wallis test is used to determine if there is a statistic significant among each category through SPSS.

\section{RESULTS AND DISCUSSION}

\section{Black-white fungus Auricularia sp.'s Phytochemical Constituents}

Three extracts of black-white fungus Auricularia sp., are labelled based on its maceration solvent, namely ethanol extract (EE), ethyl acetate extract (EAE), and n-hexane extract (HE). Several tests are conducted for phytochemical screening, which are saponins, flavonoid, tannins, glycosides, alkaloids, and triterpenoids/steroids. Phytochemical screening was done twice to unsure the results (Table 1). All of the extract results in triterpenoids positive, as has been stated in Table 1. Other than triterpenoids, EE were positive in flavonoids, whereas EAE were positive in flavonoids and alkaloids. As for HE, it had no positive results other than triterpenoid. There is no report that we could find from the previous research about the phytochemical screening for black-white fungus of Auricularia cornea. The closest result we could find is from Essien, et al. (2015), researching about the phytochemical components of Auricularia auricula. Auricularia auricula is consist of alkaloids, flavonoids, saponins, and triterpenoids/steroids. ${ }^{14}$ The slight difference from our results is black-white fungus Auricularia sp. in this work does not consist of saponins. Whereas the other components such as alkaloids, flavonoids, and triterpenoids can be found in both fungi. The difference could be cause due to different genus and different method for the phytochemical screening.

\section{TLC Analysis of Black-white Fungus Auricularia sp.}

TLC analysis of result of black-white fungus Auricularia sp. extracts is displayed in Figure 3. Mobile phase that was used is a mixture of n-hexane and ethyl-acetate with a ratio of $4: 1$, with UV lamp at 254 $\mathrm{nm}$ as a visualized spot. TLC result of Auricularia sp. could be seen in Table 2. The results are presented as retention factor (Rf). Out of the three extracts, HE has more phytochemical components with seven (7) compared to the two others, with EE and EAE both have five (5) phytochemical components. The TLC results had in total of 17 phytochemical components between the three extracts of black-white fungus of Auricularia sp. HE has the highest number of noticeable extracts with 7 , followed by EE and EAE each with 5 noticeable extracts. Each of the three extracts has 3 similar Rf value amongst each other with the Rf value of $0.375 ; 0.70$ and 0.875 for EE, $0.375 ; 0.775$ and 0.9375 for EAE, and $0.70 ; 0.775$ and 0.9375 for HE. The similar Rf below 0.5 could indicate to be more polar compared to the $\mathrm{Rf}$ above 0.5 because the mobile phase is considered polar and polar molecules

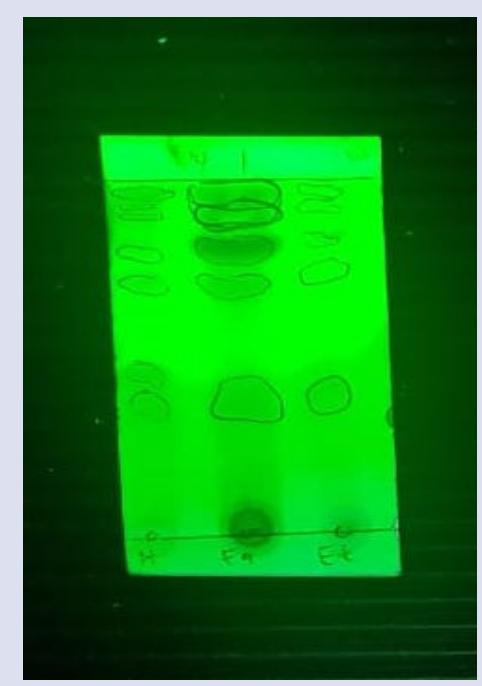

Figure 3: TLC analysis of $n$-Hexane extract (HE), Ethylacetat extract (EAE) and Ethanol extract (EA) of Black-white fungus Auricularia sp. 
Table 1: Phytochemical screening result of Black-white fungus Auricularia sp.

\begin{tabular}{lccc}
\hline & \multicolumn{3}{c}{ Black-white fungus Auricularia sp. } \\
\cline { 2 - 4 } Phytochemical & $\begin{array}{c}\text { Ethanol extract } \\
\text { (EE) }\end{array}$ & $\begin{array}{c}\text { Ethyl Acetate } \\
\text { extract (EAE) }\end{array}$ & $\begin{array}{c}\text { n-Hexane extract } \\
\text { (HE) }\end{array}$ \\
\hline Saponins & - & - & - \\
Flavonoids & + & + & - \\
Tannins & - & - & - \\
Glycosides & - & - & - \\
Alkaloids & - & + & - \\
Triterpenoids & + & + & + \\
Steroids & - & - & -
\end{tabular}

Table 2: Rf value and phytochemical components in Black-white fungus Auricularia sp.

\begin{tabular}{lll}
\hline Extract of Auricularia sp. & Rf value & $\begin{array}{l}\text { Phytochemical } \\
\text { Components }\end{array}$ \\
\hline Ethanol extract (EE) & $\begin{array}{l}0.375,0.7,0.8,0.875,0.925 \\
\text { Ethyl acetate extract (EAE) }\end{array}$ & $\begin{array}{l}0.375,0.675,0.775,0.8625, \\
0.9375\end{array}$ \\
& $\begin{array}{l}0.35,0.45,0.7,0.775,0.875, \\
\text { n-Hexane extract (HE) }\end{array}$ & 7 \\
& $0.9,0.9375$ &
\end{tabular}

are more soluble in polar solvents. This indicates that from the three extracts, there are similarities and different components, which needs further research to explore it.

\section{Antioxidant Activity of Black-white Fungus Auricularia sp.}

Antioxidant activity of black-white fungus Auricularia sp. is measured by DPPH assay through the radical scavenging activity. The results from test were identify as IC50 value, which is amount of extract concentration to reach $50 \%$ inhibition. ${ }^{12}$ The radical scavenging activity could be influenced by the phytochemical components of the extracts. Secondary constituents such as flavonoids, tannins, have showed that they have antioxidant biological activities.

Only two out of three extract of Auricularia sp. can be analyzed. HE was not included due to having a characteristic of non-polar which is not dissolved in ethanol as a polar solvent for DPPH assay. The positive control has been established by using ascorbic acid, which have very active antioxidant activity as reported by Pehlivan et al. $(2017)^{15}$. The antioxidant activity test on DPPH was done three time. The linear regression equation of $y=a x+b$ is obtained by plotting of concentration of the extract in $\mathrm{x}$ axis versus percentage of inhibition in $y$ axis. Substitution of $y$ with 50 in linear regression of $y=a x+b$ will give $\mathrm{x}$ value which is equivalent with IC50 value. The IC50 value for ascorbic acid, EE, and EAE, were $0.782 \mu \mathrm{g} / \mathrm{mL} ;>1000 \mu \mathrm{g} / \mathrm{mL}$; and $215.51 \mu \mathrm{g} / \mathrm{mL}$, respectively (Table 3 ). The linear regression equation for $\mathrm{EE}$ is $\mathrm{y}=15,054 \mathrm{x}-25,214$ with $\mathrm{R} 2=0.9618$. Whereas the linear regression equation for $\mathrm{EAE}$ is $\mathrm{y}=25,979 \mathrm{x}-10,624$ with $\mathrm{R}^{2}=0.9856$. Both of the linear regression can be seen in Figure 4.

Antioxidant properties of Auricularia sp. extracts are categorized based on its IC50 value as provided by Marjoni et al. (2017) ${ }^{16}$, with the following orders that could be seen in Table 4 . From the data that has been gathered, EE is categorized as not active (IC50 >1000 $\mu \mathrm{g} /$ $\mathrm{mL}$ ), whereas EAE is classified into having a moderate antioxidant activity (IC50: $215.51 \mu \mathrm{g} / \mathrm{mL}$ ), compared to the control group of ascorbic acid, which categorized very active (IC50: $0.782 \mu \mathrm{g} / \mathrm{mL}$ ). From phytochemical screening, it was stated that EE is positive in flavonoid and alkaloid, compared to ethanol extract only positive in flavonoid. This could lead to ethyl acetate extract having a lower IC50 than ethanol extract. Gebreyohannes et al. (2019), used Auricularia sp. and extracted it with three solvent which are chloroform, $70 \%$ of ethanol, and hot water, resulting in chloroform extract, ethanol extract, and hot water extract, respectively. ${ }^{17}$ The three extracts undergone DPPH assay to determine the scavenging activities of the extracts. Considering the classification by Marjoni ${ }^{16}$, ethanol extract is categorized as very active (IC50: $40 \mu \mathrm{g} / \mathrm{mL}$ ), whereas chloroform (IC50:50 $\mu \mathrm{g} / \mathrm{mL}$ ) and hot water (IC50: $60 \mu \mathrm{g} / \mathrm{mL}$ ) is categorized as active. ${ }^{17}$ The difference results between this research and Gebreyohannese research may be due to the origin of the plant and different method of extracting the fungus.

\section{Cytotoxicity of Black-white fungus Auricularia $s p$. towards breast MCF-7 Cells}

MTT assay is used to determine the cytotoxicity evaluation of blackwhite fungus Auricularia sp. extracts towards MCF-7 breast cancer cells. Cytotoxic activities of Auricularia sp. extracts against breast MCF7 cancer cells are presented in IC50 value (Table 5). The results indicate a relatively low overall of IC50 value of all of the extracts, recorded below $100 \mu \mathrm{g} / \mathrm{mL}$. This indicates that there is cytotoxic activity in all of the extract, with the strongest cytotoxic activity is the EAE (IC50: 0.21 $\mu \mathrm{g} / \mathrm{mL}$ ), followed by EE (IC50: $29.28 \mu \mathrm{g} / \mathrm{mL}$ ), and HE (IC50: $50.39 \mu \mathrm{g} /$ $\mathrm{mL})$. Doxorubicin was used as the positive control, had a small IC50 value (IC50: $0.020 \mu \mathrm{g} / \mathrm{mL}$ ). The results are compared to an established classification by Atjanasuppat et al. (2009) which is presented in Table $6 .^{18}$ Based on the cytotoxicity classification by Atjanasuppat et al., EE and $\mathrm{HE}$ are classified into the active classification (IC50: 20-100 $\mu \mathrm{g} /$ $\mathrm{mL}$ ), while EAE is classified into the very active classification (IC50 < $20 \mu \mathrm{g} / \mathrm{mL}$ ). These results could be benefit towards MCF-7 cancer cells by being categorized active and very active cytotoxic activity and needs to be explored extensively. Novaković et al. (2016) reported about the cytotoxic activity of Auricularia auricula-judae towards MCF-7 breast cancer cell line with MTT assays. Using two extracts, which are ethanol extract with IC50 of $333.3 \mu \mathrm{g} / \mathrm{mL}$ and water extract with IC50 of 285.7 $\mu \mathrm{g} / \mathrm{mL}$ against MCF-7 cells ${ }^{19}$, showed that both extracts are categorized into the moderate cytotoxicity on MCF-7 cells (IC50: 100-1000 $\mu \mathrm{g} /$

Table 3. IC $C_{50}$ value of ascorbic acid and Auricularia sp. extracts on DPPH.

\begin{tabular}{lc|}
\hline Sample & $\mathrm{IC} 50(\mu \mathrm{g} / \mathrm{mL})$ on DPPH \\
\hline Ascorbic acid & 0.782 \\
Ethanol extract of Auricularia sp. (EE) & $>1000$ \\
Ethylacetate extract of Auricularia sp. (EAE) & 215.51
\end{tabular}

Table 4: Marjoni et al, ${ }^{16}$ Antioxidant Activity Classification.

\begin{tabular}{cc}
\hline $\mathrm{IC}_{50}(\mu \mathrm{g} / \mathrm{mL})$ & Antioxidant Classification \\
\hline $50(\mu \mathrm{g} / \mathrm{mL})$ & Very active \\
$50-100(\mu \mathrm{g} / \mathrm{mL})$ & Active \\
$100-250(\mu \mathrm{g} / \mathrm{mL})$ & Moderate \\
$250-500(\mu \mathrm{g} / \mathrm{mL})$ & Weak \\
$>500(\mu \mathrm{g} / \mathrm{mL})$ & Not active
\end{tabular}

Table 5: IC $\mathrm{C}_{50}$ value $(\mu \mathrm{g} / \mathrm{mL})$ of Black-white fungus Auricularia sp. extracts on breast MCF-7 cells.

\begin{tabular}{|cc|}
\hline Tested sample & $\mathrm{IC}_{50}(\mu \mathrm{g} / \mathrm{mL})^{*}$ \\
\hline Doxorubicin (positive control) & 0.020 \\
n-Hexane extract (HE) & 50.39 \\
Ethyl acetate extract (EAE) & 0.21 \\
Ethanol extract (EA) & 29.28 \\
\hline
\end{tabular}

${ }^{*} \mathrm{IC} \mathrm{C}_{50}$ is the median inhibitory concentration in $\mu \mathrm{g} / \mathrm{mL}$.

Table 6: Cytotoxicity Classification Activity by Atjanasuppat et al. ${ }^{18}$

\begin{tabular}{cc}
\hline $\mathrm{IC}_{50}(\mu \mathrm{g} / \mathrm{mL})$ & Classification \\
$<20(\mu \mathrm{g} / \mathrm{mL})$ & Very active \\
$20-100(\mu \mathrm{g} / \mathrm{mL})$ & Active \\
$100-1000(\mu \mathrm{g} / \mathrm{mL})$ & Moderate \\
$>1000(\mu \mathrm{g} / \mathrm{mL})$ & Not Active
\end{tabular}




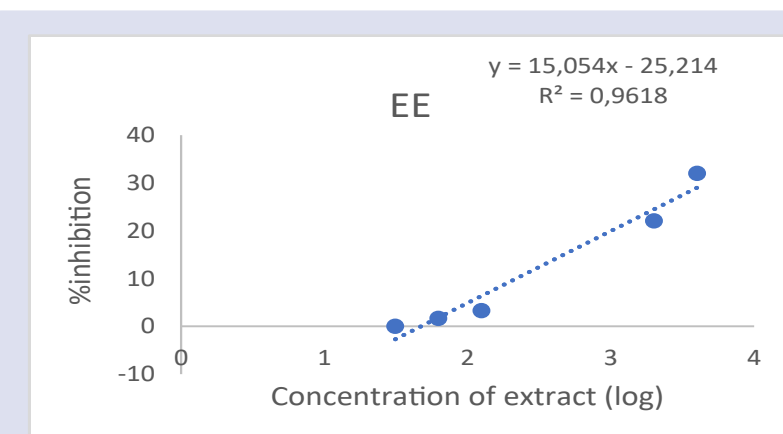

(4a)

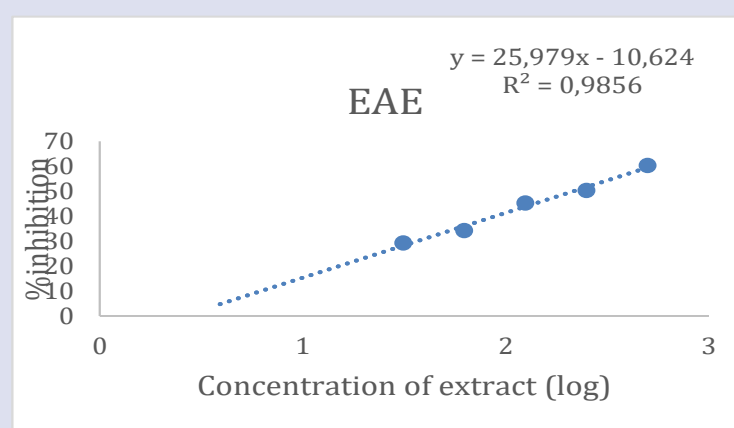

(4b)

Figure 4: Linear graph of EE (4a) and EAE (4b) of black-white fungus Auricularia sp. on DPPH.

$\mathrm{mL}$ ), according to classification by Atjanasuppat. The EE of black-white fungus Auricularia sp. in this research had a lower IC50 value compared to Auricularia auricula-judae. This phenomenon could be caused by the different genus and method of extracting by respective researchers.

\section{CONCLUSION}

Black-white fungus Auricularia sp. contained flavonoids, alkaloid, and triterpenoids as its secondary metabolites and had a total of 17 phytochemical components from the TLC analysis. Ethyl acetate extract (EAE) of Black-White fungus Auricularia sp. had a moderate antioxidant activity, on the other hand ethanol extract (EE) was considered as not active towards DPPH free radical. Ethanol extract (EE) and n-hexane extract (HE) of black-white fungus Auricularia sp. extract had an active cytotoxic activity, whereas ethyl acetate extract (EAE) had a very active cytotoxic activity towards MCF-7 breast cancer cells.

\section{ACKNOWLEDGEMENT}

The author would like to thank KEMENRISTEK-BRIN, Republic of Indonesia for the PDUPT research grant for fiscal year 2020 (contract number: NKB-2735/UN2.RST/HKP.05.00/2020), as well as to Directorate of Research and Public Service (DRPM), University of Indonesia for the PUTI Q3 research grant for fiscal year 20202021 (contract number: NKB-1901/UN2.RST/HKP.05.00/2020). Furthermore, the authors also would like to thank their family and friends for the endless support.

\section{CONFLICTS OF INTEREST}

The authors declare no conflicts of interest.

\section{ABBREVIATIONS}

TLC: Thin layer chromatography; DPPH: (2,2-diphenyl1-picrylhydrazyl) MTT: (3-(4,5-Dimethylthiazol-2-yl)-2,5Diphenyltetrazolium Bromide); DMSO: dimethyl sulfoxide; IC $_{50}$ : median Inhibitory Concentration; $\boldsymbol{\mu g} / \mathbf{m L}$ : microgram/milliliter; MCF-7: Michigan Cancer Foundation-7 g: gram; mL: millimeter; N: Normality; UV-Vis: Ultra violet-Visible, RPMI: Rosewell Park Memorial Institute; h: hour; PBS: Phosphate-Buffered Saline; ${ }^{\circ} \mathbf{C}$ : degree Celsius; $\boldsymbol{\mu L}$ : microliter; $\mathbf{C O}_{2}$ : Carbon dioxide; Rf: Retention factor; USA: United States of America.

\section{REFERENCES}

1. Kaplan W. Background paper 6.5 cancer and cancer therapeutics [Internet]. 2013 [cited 2020 Jan 17]. Available from: https://www. who.int/medicines/areas/priority_medicines/BP6_5cancer.pdf

2. Worlds Health Organization. Latest global cancer data: cancer burden rises to 18.1 million new cases and 9.6 million cancer deaths in 2018 [Internet]. 201 [cited 2019 Nov 23]. Available from: http://gco.iarc.fr/
3. Anjum F, Razvi N, Masood MA. Breast cancer therapy: A mini review. MOJ Drug Des Dev Ther. 2017;1(2).

4. World Health Organization. Diagnosis and treatment [Internet] Geneva: World Health Organization [cited 2020 Jan 17]. Available from: https://www.who.int/cancer/prevention/diagnosis-screening/ breast-cancer/en/

5. Aslam MS, Naveed S, Ahmed A, Abbas Z, Gull I, Athar MA. Side effects of chemotherapy in cancer patients and evaluation of patients opinion about starvation based differential chemotherapy. J Cancer Ther. 2014;05(08):817-22.

6. Lovitt CJ, Shelper TB, Avery VM. Doxorubicin resistance in breast cancer cells is mediated by extracellular matrix proteins. BMC Cancer. 2018;18(1):1-11.

7. Petrova RD, Wasser SP, Mahajna JA, Denchev CM, Nevo E. Potential role of medicinal mushrooms in breast cancer treatment: current knowledge and future perspectives. Int J Med Mushrooms. 2005;7(1-2):141-55.

8. Philpott HG, James NG TH. Auricularia cornea (wood-ear fungi) [Internet]. Taranaki Educational Resource: Research, Analysis and Information Network. 2018 [cited 2020 Jun 12]. Available from: http://www.terrain.net.nz/friends-of-te-henui-group/fungi-te-henui/ jews-ear-fungi.html

9. Cai L. Thin layer chromatography. Curr Protoc Essent Lab Tech. 2014;6(3):1-18.

10. Bandiola TM. Screening of medicinal plants for. Int J Pharm. 2018;8(1):137-43.

11. Tiwari $P$, Kumar B, Kaur MKGK. Phytochemical screening and extraction: a review. Int Pharm Sci. 2011;1(1):1866-84.

12. Shimamura T, Sumikura Y, Yamazaki T, Tada A, Kashiwagi T, Ishikawa $\mathrm{H}$, et al. Applicability of the DPPH assay for evaluating the antioxidant capacity of food additives - inter-laboratory evaluation study. Anal Sci. 2014;30(7):717-21.

13. Stacey GN. Cancer cell culture, MTT assay. Methods Mol Biol [Internet]. 2011 [cited 2020 Jun 12];731(1):79-91. Available from: http://link.springer.com/10.1007/978-1-61779-080-5

14. Essien EE, Mkpenie VN, Akpan SM. Phytochemical and mineral elements composition of bondazewia berkeleyi, auricularia auricula and ganoderma lucidum fruiting bodies. RJBCS. 2015;6(2):200-4.

15. Pehlivan FE. Vitamin C: an antioxidant agent. InTech. 2017;2:24-35.

16. Marjoni MR, Zulfisa A. Antioxidant activity of methanol extract/ fractions of senggani leaves (melastoma candidum d. don). Pharm Anal Acta. 2017;8(8):1-6.

17. Gebreyohannes G, Nyerere A, Bii C, SBhatu DB. Investigation of antioxidant and antimicrobial activities of different extracts of Auricularia and Termitomycytes species of mushroom. The Scientific World Journal. 2019 Jul:1-10. 
18. Atjanasuppat K. Wongkham W, Meepowpan P, Kittakoop P, Sobhon $P$, Bartlett $A$, Whitfield PJ. In vitro screening for anthelmintic and antitumour activity of ethnomedicinal plants from Thailand. J.Ethnopharmacol. 2009;123:475-82
19. Novaković A, Karaman M, Kaišarević S, Radusin T, Beribaka M, llić N. auricularia auricula - judae (Bull.:Fr.) wettst. 1885 cytotoxicity on breast cancer cell line (MCF 7). University of Novi Sad, Institute of Food Technology. 2016 Oct; 18: 112-5

\section{GRAPHICAL ABSTRACT}

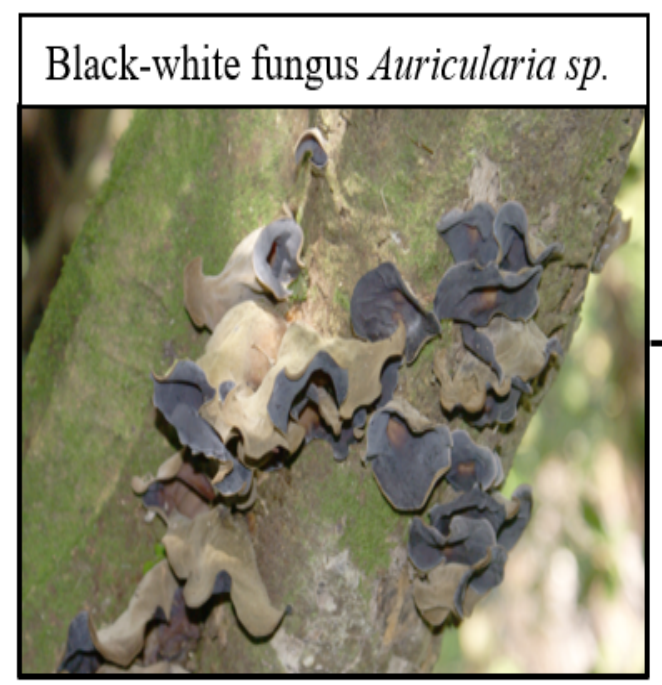

\section{Hexane extract}

IC50: $50.39 \mathrm{\mu g} / \mathrm{mL}$ on MCF-7 cells

1. Extraction with nhexane, ethylacetate and ethanol

2. Antioxidant and cytotoxicity evaluation on MCF-7 cells

\section{Ethylacetate extract}

IC50: $215.51 \mu \mathrm{g} / \mathrm{mL}$ on DPPH IC50: $0.21 \mathrm{\mu g} / \mathrm{mL}$ on MCF-7 cells

\section{Ethanol extract}

IC50: $>1000 \mathrm{\mu g} / \mathrm{mL}$ on DPPH IC50: $29.28 \mathrm{\mu g} / \mathrm{mL}$ on MCF-7 cells

\section{SUMMARY}

Black-White fungus Auricularia sp. contained flavonoids, alkaloid, and triterpenoids as its secondary metabolites and had a total of 17 phytochemical components. Ethyl acetate extract (EAE) of black-white fungus Auricularia sp. had a moderate antioxidant activity. Ethanol extract (EE) and n-hexane extract (HE) of black-white fungus Auricularia sp. extract had an active cytotoxic activity, whereas ethyl acetate extract (EAE) had a very active cytotoxic activity towards MCF-7 breast cancer cells. 


\section{ABOUT AUTHORS}
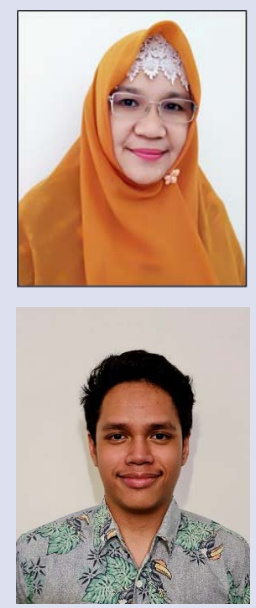

Dr. Ade Arsianti: Lecturer and Researcher at Medical Chemistry Department and Drug Development Research Center (DDRC), Indonesian Medical Education and Research Institute (IMERI), Faculty of Medicine, Universitas Indonesia. Research interest in medicinal chemistry, synthetic organic chemistry, synthesis of nanoparticle, natural product chemistry, and marine natural product.

Arfi Rabbani: Fourth-year medical student in Faculty of Medicine, Universitas Indonesia. Cancer is one of the non-communicable diseases that cause a significant amount of morbidity and mortality. Treating cancer with the newest technology will cost a fortune with various side effects. The author is interested to find an alternative through active components found in fungi that have antioxidant and cytotoxic activity towards cancer cells, especially MCF-7 breast cancer cells. Hopefully this research could produce an alternative treatment that is cost effective.

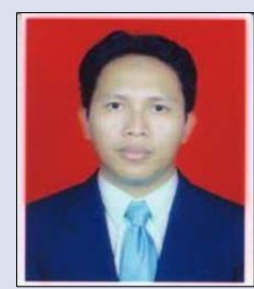

Dr. Anton Bahtiar: Lecturer and Researcher at Department of Pharmacology, Faculty of Pharmacy, Universitas Indonesia. Research interest in molecular pharmacology and herbal medicine.

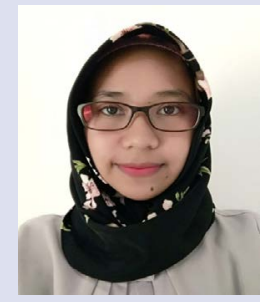

Norma Nur Azizah: Researcher at Drug Development Research Center (DDRC), Indonesian Medical Education and Research Institute (IMERI), Faculty of Medicine, Universitas Indonesia. Research interest in tissue culture, analytical chemistry, and natural product chemistry.

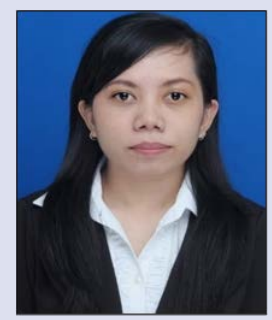

Lince Dameria Nadapdap: Researcher at Drug Development Research Center (DDRC), Indonesian Medical Education and Research Institute (IMERI), Faculty of Medicine, Universitas Indonesia. Research interest in synthetic organic chemistry, analytical chemistry, and natural product chemistry.

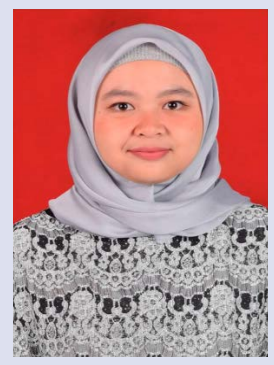

Ajeng Megawati Fajrin: Researcher at Department of Medical Chemistry, Faculty of Medicine, Universitas Indonesia. Research interest in tissue culture, analytical chemistry, and natural product chemistry.

Cite this article: Arsianti A, Rabbani A, Bahtiar A, Azizah NN, Nadapdap LD, Fajrin AM. Phytochemistry, Antioxidant Activity and Cytotoxicity Evaluation of Black-White Fungus Auricularia sp. against Breast MCF-7 Cancer Cells. Pharmacogn J. 2022;14(1):1-7. 